\title{
Cytotoxic Activity of Some Tanzanian Medicinal Plants
}

\section{D.K.B. RUNYORO ${ }^{1}$, A. KAMUHABWA ${ }^{* 1}$, O.D. NGASSAPA ${ }^{1}$ AND P. de WITTE ${ }^{2}$}

'Department of Pharmacognosy, School of Pharmacy, Muhimbili University College of Health Sciences, P.O Box 65013, Dar Es Salaam, Tanzania.

${ }^{2}$ Laboratory of Pharmaceutical Biology and Phytopharmacology, Faculty of Pharmacy, Catholic University of Leuven, Belgium.

Thirty-three aqueous methanolic extracts obtained from thirty plant species, belonging to seventeen families were screened for cytotoxic activity against HeLa (Human cervical carcinoma) cells. The ability of the extracts $(10 \mu \mathrm{g} / \mathrm{ml}$ and $1 \mu \mathrm{g} / \mathrm{ml}$ ) to inhibit proliferation of HeLa cells was determined using the 3-(4,5dimethylthiazol-2-yl)-2,5-diphenyl-tetrazolium bromide (MTT) dye reduction assay. Extracts from roots of Agathisanthemum bojeri, Synaptolepis kirkii and Zanha africana and the leaf extract of Physalis peruviana at a concentration of $10 \mu \mathrm{g} / \mathrm{ml}$ inhibited cell proliferation by $58.3 \%, 68.1 \%, 75.7 \%$ and $91.8 \%$, respectively. The remaining 29 extracts exhibited no pronounced cytotoxic activity at the tested concentrations. It is worth investigating the four extracts, which showed pronounced cytotoxic activity so as to isolate and identify the compounds responsible for cytotoxic activity.

Key words: $\quad$ Cytotoxic plants, Tanzanian medicinal plants, Agathisanthemum bojeri, Synaptolepis kirkii, Zanha africana, Physalis peruviana

\section{INTRODUCTION}

Cancer has been managed through surgery, chemotherapy and radiotherapy, unfortunately with rather limited success. The chemotherapeutic agents, though effective against various types of tumors, are not totally free from side effects; some of them may even be carcinogenic [1-2]. Hence there is a need for the continued search for anticancer agents from plants as they are less likely to cause serious side effects [3]. Hartwell [4-5] listed down more than 1400 genera used in folk medicine to treat cancer.

Plants are a rich source of structurally diverse chemical compounds and have been used for centuries to cure various ailments. Compounds derived from plants have been an important source of useful anti-cancer agents such as vinblastine, vincristine, paclitaxel, the camptothecin derivatives (topotecan and irinotecan) and etoposide (derived from podophyllotoxin) [6].

Tanzania is a country blessed with a rich biodiversity, with natural forests containing over 10,000 species with a high degree of diversity as well as endemicity [7]. Hence the possibility of obtaining effective drugs for various diseases is immense. In the current study, extracts from 30 plant species were evaluated for their in vitro cytotoxicity on human cervical carcinoma cells.

\section{MATERIALS AND METHODS}

\section{Collection of plant materials}

The plants used in this study were sampled from among plants previously collected for in vitro evaluation of anticandida activity in 2003. They were collected from four regions of Tanzania namely Coast, Dar es Salaam, Morogoro and Tanga. They were identified in the field by a botanist and their identity was confirmed at the herbarium of the Department of Botany of the University of Dar es Salaam, Tanzania, where their respective voucher specimens are deposited.

\section{Preparation of plant materials and extracts}

The plant materials were dried in the open air under the sun with delicate organs like leaves being dried in the sun for one day and then in the shade. The plant materials were ground and 100 to $200 \mathrm{~g}$ of each plant material was macerated with $80 \%$ aqueous methanol at room temperature ( 28 
$\left.{ }^{\circ} \mathrm{C}\right)$. Maceration was carried out for two days and the procedure was repeated three times. Extracts were pooled together and concentrated under vacuum using a Büchi rotary evaporator (Büchi Labortechnik, Flawil, Switzerland) set at 40-50 ${ }^{\circ} \mathrm{C}$, followed by freeze-drying using the Edwards freeze drier (Edwards High Vacuum International Crawley, Sussex, England). The dry extracts were stored in plastic containers in a freezer, at $-20^{\circ} \mathrm{C}$, until when needed for testing.

\section{Cell culture}

HeLa (human cervical carcinoma) cells were obtained from American Type Culture Collection (Rockville, MD, USA). MTT (3-(4,5dimethylthiazol-2-yl)-2,5-diphenyl-tetrazolium bromide) was purchased from Sigma (St. Louis, MO, USA). Minimum Essential Medium (MEM), L-glutamine, non-essential amino acids, penicillin, streptomycin, tylocin, amphotericn B, fetal calf serum (FCS) and phosphate-buffered saline (PBS) were obtained from Gibco BRL (Paisley, Scotland, UK). Microtitre tissue culture plates were purchased from Falcon (NJ, USA) and dimethylsulfoxide (DMSO) from Sigma (Poole, Dorset, England).

\section{Cytotoxicity assay}

Extracts were first dissolved in DMSO to make stock solutions and then diluted in culture medium to yield extract solution with a final DMSO concentration of $0.1 \%$. This final concentration of DMSO did not affect cell viability. Cells were seeded onto 96-well microtitre tissue culture plates at $5 \times 10^{3}$ cells per well and incubated for $24 \mathrm{~h}$ at $37{ }^{\circ} \mathrm{C}$ in humidified $5 \% \mathrm{CO}_{2}$ and $95 \%$ air atmosphere. Afterwards the medium was replaced with fresh medium containing different concentrations of extracts $(10 \mu \mathrm{g} / \mathrm{ml}$ and $1 \mu \mathrm{g} / \mathrm{ml})$ or the vehicle. The cells were then incubated at 37 ${ }^{\circ} \mathrm{C}$ for $72 \mathrm{~h}$. The extract-containing medium was then removed and cell proliferation was determined using the MTT dye reduction assay. MTT was dissolved $(1 \mathrm{mg} / \mathrm{ml})$ in PBS $(0.01 \mathrm{M}$; $\mathrm{pH} 7.4$ ) and added to the cells and the plates were incubated at $37{ }^{\circ} \mathrm{C}$ for $4 \mathrm{~h}$. MTT solution was carefully removed and $100 \mu \mathrm{l}$ of DMSO was added to each well in order to dissolve the formed formazan crystals. The plates were read on a microtitre plate reader (SLT, Salzburg, Austria) at $550 \mathrm{~nm}$. The results were expressed as a percentage of cell survival as compared to the control. All experiments were performed in triplicate.

\section{RESULTS AND DISCUSSION}

Thirty-three aqueous methanolic extracts obtained from thirty species belonging to seventeen families were subjected to cytotoxicity test using HeLa (human cervical carcincma) cells. The results (Table 1) are given as average inhibition of proliferation of HeLa cells as a percentage of control. Fifteen plant extracts showed no inhibition of proliferation of HeLa cells at a concentration of $1 \mu \mathrm{g} / \mathrm{ml}$, of which 6 did not exhibit activity even when the concentration was raised to $10 \mu \mathrm{g} / \mathrm{ml}$. Most extracts showed a slight increase of activity on increasing the concentration with the exception of Boscia salicifolia, Elaeodendron . buchananii, Pseudolachnostylis maprouneaefolia, Securidaca longepedunculata and Vitex fischeri. These extracts probably had some nutritive values that enhanced cell growth hence the observed increase in cell proliferation when their concentrations were raised to $10 \mu \mathrm{g} / \mathrm{ml}$ (Tablè 1).

Only seven out of the 30 screened plants showed inhibition of proliferation of HeLa cells of about $25 \%$ or more. It could be observed also that in the case of Agathisanthemum bojeri the activity varied depending on the plant part used; the roots were found to be active whereas the aerial parts were almost devoid of activity. This shows that these parts may contain different compounds to which the observed discrepancies may be attributed. In the case of $P$. maprouneaefolia, the stem and root bark behaved similarly in that both were devoid of the activity.

Six out of the 30 studied plants have been reported to be used in folk medicine for the treatment of tumors, swelling, inflammation or cancer [8-12]. Zanha africana is used in traditional medicine for inflammation and in this study it was shown to inhibit the proliferation of HeLa cells. 
$\overline{\bar{g}}$

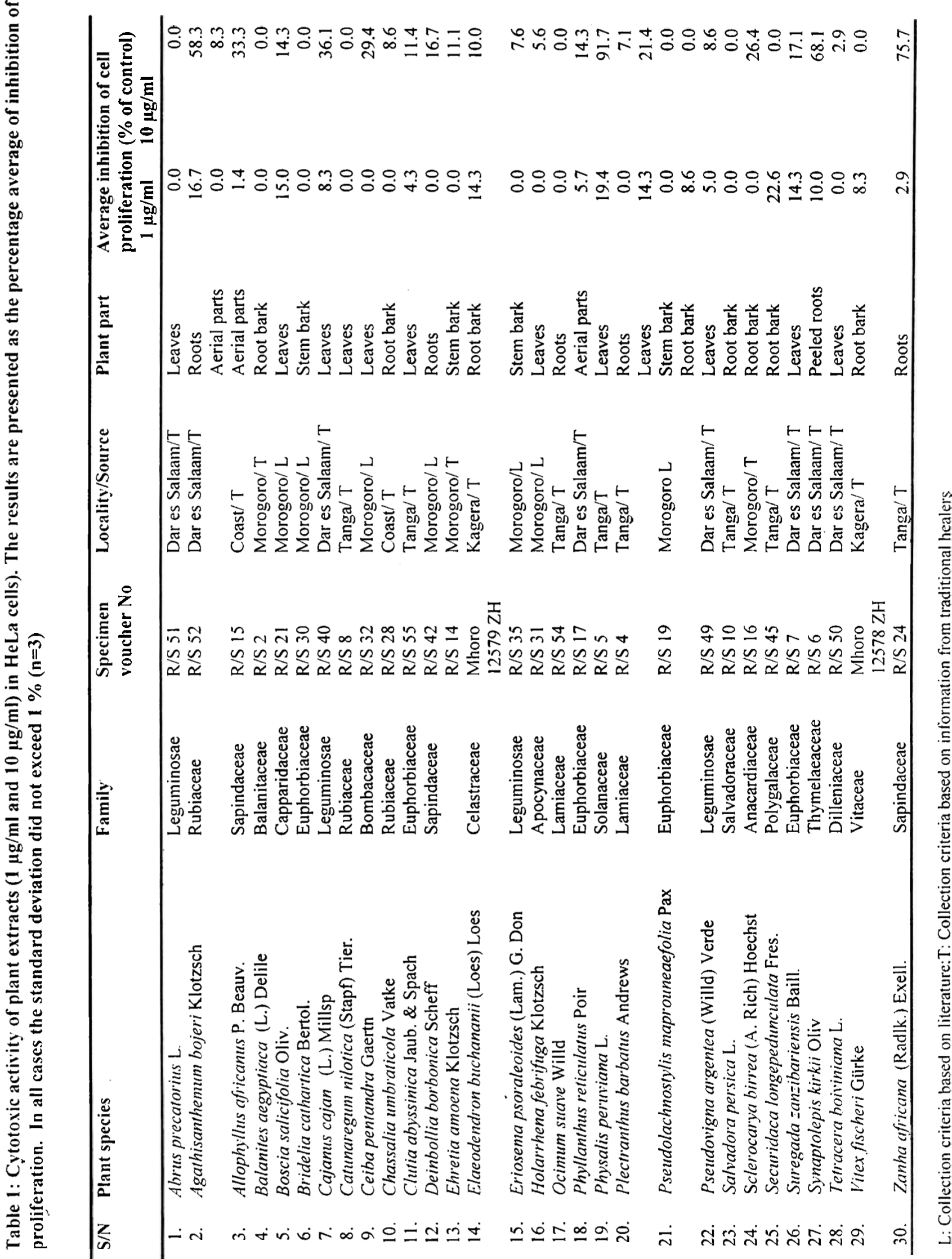


Twenty plants (representing $67 \%$ of those studied) were evaluated for the first time and three plants namely $A$. bojeri, Physalis peruviana and Synaptolepis kirkii were able to inhibit the proliferation of cells by more than $50 \%$ when compared to the control. The remaining plants (33 $\%$ ) have been previously evaluated using various cell lines including HeLa, LEUK-P388, CA-9KB, WI-38, SARCOMA (YOSHIDA ASC), SARCOMA (YOSHIDA SOLID) and THPI. The reported results ranged from being inactive to being very active [13-20]. As seen from the results (Table 1), four plants namely $A$. bojeri, $P$. peruviana, $S$. kirkii and $Z$. africana displayed high activity inhibiting cell proliferation by $58.3 \%$, $91.8 \%, 68.1 \%$ and $75.7 \%$ respectively, at a concentration of $10 \mu \mathrm{g} / \mathrm{ml}$. These plants therefore deserve further evaluation so as to isolate the active cytotoxic compounds. These plants were initially collected through interviews with traditional healers who reported that they were used for the treatment of candidiasis. The dichloromethane and ethanolic extracts of $Z$. africana have been reported previously to show moderate activity on LEUK-P815 cells at a concentration of $1.25 \mu \mathrm{g} / \mathrm{ml}^{\prime}$ [17]. The dichloromethane extract of the root bark was also reported to be active on HeLa cells at a concentration of $6.5 \mu \mathrm{g} / \mathrm{ml}$ while the ethanolic extract was inactive at $200 \mu \mathrm{g} / \mathrm{ml}$ [18]. The dichloromethane extract of the same plant part at the concentration of $6.75 \mu \mathrm{g} / \mathrm{ml}$ was active on CA HUMAN COLON-CO 115 cells while the methanolic extract at a concentration of $100 \mu \mathrm{g} / \mathrm{ml}$ was inactive [21].

In the present study the aqueous methanolic extract of the roots of $Z$. africana was found to be active even though previous studies have indicated that alcoholic extracts were inactive. Further study could be done on the plant to include non-polar extracts and using several cell lines since cytotoxic compounds act differently on various cell lines.

\section{CONCLUSION}

From this study it can be concluded that four extracts of plants obtained from traditional healers exerted more than $50 \%$ inhibition of proliferation of HeLa cells when compared to the control. It is suggested that these plants be studied further so as to isolate the compounds responsible for cytotoxic activity.

\section{ACKNOWLEDGEMENTS}

The authors would like to thank Mr. Jan Maes of the Laboratory of Pharmaceutical Biology and Phytopharmacology, Faculty of Pharmacy, Catholic University of Leuven, Belgium, for helping in carrying out the cytotoxicity assay.

\section{REFERENCES}

[1] J.E.F Reynolds, K. Parfitt, A.V. Parsons and S.C. Sweetman, (eds). Martindale. The Extra Pharmacopoeia. $31^{\text {st }}$ Ed. Royal Pharmaceutical Society, London. 1996, p.512 and 594.

[2] G.D. Leonard, M.R., Wagner M.G. Quinn and J.L. Grem. Anti-cancer Drugs 15 (2004) 733-5.

[3] S. Kaur, H. Michael, S. Arora, P.L. Härkönen and S. Kumar. J. Ethnopharmacol. 97 (2005) 15-20.

[4] J.L. Hartwell. Lloydia 31 (1968) 71-170.

[5] J.L. Hartwell. Lloydia 32 (1969) 79-107.

[6] G.M. Cragg and D.J. Newman. J. Ethnopharmacol. 100 (2005) 72-79.

[7] K.E. Mshigeni, M.H.H. Nkunya, V. Fupi, R.L.A. Mahunnah and E.N. Mshiu (eds). Proceedings of International Conference on Traditional Mededicinal Plants; 1990 Feb 18-23; Arusha, Tanzania. Dar es Salaam University Press. 1991, p 83.

[8] I. Hedberg, O. Hedberg, P.J. Madati, K.E. Mshigeni, E.N. Mshiu and G. Samuelsson J. Ethnopharmacol. 9 (1983) 105-127.

[9] J.A. Duke and E.S. Ayensu. Medicinal plants of China. Reference Publications, Book 1, Inc. Algonac, Michigan. 1985, p 52. 
[10] A.H. Shah, M. Tariq, A.M. Ageel and S. Quareshi. Fitoterapia 60 (1989) 171-173.

[11] S.C. Chhabra, R.L.A. Mahunnah and E.N. Mshiu. J. Ethnopharmacol. 33 (1991) 143-157.

[12] A. Trovato, S. Kirjavainen, F.M. Galati, A.M. Forestieri and L. Iauk. Phytother. Res. 9 (1995) 591-593.

[13] M.L. Dhar, M.M. Dhar, B.N. Dhawan, B.N. Mehrotr and C. Ray. Indian J. Exp. Biol. 6 (1968) 232-247.

[14] M. Tomita, T. Kurokawa, K. Onozaki, T. Osawa, Y. Sakurai and T. Ukita. Int. J. Cancer 10 (1972) 602-605.

[15] M. Suffness, B. Abbott, D.W. Statz, E. Wonilowicz and R. Spjut. Phytother. Res. 2 (1988) 89-97.

[16] G.R. Pettit, D.L. Doubek, D.L. Herald, A. Numata, C. Takahasi and R.T. Fujiki,
Miyamoto. J. Nat. Prod. 54 (1991) 14911502.

[17] D. Ottendorfer, J. Frevert, R. Kaufmann, N. Beuscher, C. Bodinet, I.D. Msonthi, A. Marston, and K. Hostettmann. Phytother. Res. 8 (1994) 383-390.

[18] N. Beuscher, C. Bodinet, D. NeumannHaefelin, A. Marston and K. Hostettmann. J. Ethnopharmacol. 42 (1994) 101-109.

[19] F. Freiburghaus, E.N.E. Ogwal, M.H.H. Nkunya, R. Kaminsky, and R. Brun. Trop. Med. Int. Health 1 (1996) 765-771.

[20] C. Ancolio, N. Azas, V. Mahiou, E. Ollivier, C. Di Giorgio, A. Keita, D.P. Timon, and G. Balansard. Phytother. Res. 16 (2002) 646-649.

[21] J.C. Chapuis, B.Sordat, and K. Hostettmann. J. Ethnopharmacol. 23 (1988) 273-284. 